\title{
Nilai Nutrisi Maggot Black Solder Fly (Hermetia Illucens) dengan Berbagai Media
}

\author{
Santi*, Andi Tenri Bau Astuti, Jimmy Pasamboang \\ Program Studi Peternakan Fakultas Ilmu Pertanian Universitas Al Asyariah Mandar \\ *Email : santipeternakan@gmail.com
}

\begin{abstract}
Abstrak
Maggot Lalat tentara hitam (Hermetia illucens) merupakan salah satu jenis insekta yang memiliki kandungan protein tinggi yang bagus digunakan sebagai pakan unggas. Tujuan dari penelitian ini adalah untuk mengoptimalkan produksi kandungan nutrisi maggot dengan penggunaan media feses ayam dengan ampas tahu. Penelitian ini dilaksanakan di mini rancs petrenakan, Universitas AL-Asyariah Mandar dan akan dilanjutkan dengan analisis nutrisi di Laboratorium Kimia Pakan Fakultas Peternakan UNHAS. Penelitian ini dirancang dengan menggunakan metode RAL dengan 4 perlakuan 3 ulangan, sehingga jumlah unit percobaan yaitu $12 . \mathrm{P} 1=$ ampas tahu $100 \%$ P2 $=$ ampas tahu 50\% + feses ayam 50\% P3 = ampas tahu 75\% + feses ayam 25\% P4 = ampas tahu 25\% + feses ayam $75 \%$. Kualitas produksi nutrisi paling tinggi pada perlakuan P3 dengan kadar bahan kering 30,47\%, protein kasar 42,98\%, lemak kasar $34,09 \%$, dan serat kasar 10,40\%.
\end{abstract}

Kata Kunci : ampas tahu, feses ayam, lalat tentara hitam, maggot

\section{Pendahuluan}

Jumlah penduduk Indonesi terus meningkat setiap tahunnya yang berbanding lurus dengan kesadaran masyarakat akan pentingnya perotein hewani dalam pemenuhan gizi. Salah satu komoditas protein hewani yang paling diminati masyarakat yaitu daging ayam.Data Badan Pusat Statistika (2012) menunjukkan terjadi peningkatan konasumsi daging ayam ras sebesar $1,27 \%$ / tahun dengan rerata konsumsi yaitu $3,75 \% \mathrm{~kg} / \mathrm{kapita} / \mathrm{tahun}$.

Meningkatnya konsumsi masayarakat terhadap daging broiler menjadi kabar baik bagi peternak untuk menigkatkan produksi. Hal tersebut terkendala dari harga pakan yang cukup tinggi. Biaya pakan $50-70 \%$ dari biaya prouksi, sehingga keberhasilan peternak sangat bergantung dari pakan.

Bahan pakan sumberprotein menjadi perhatian khusus karena harganya yang tinggi dan bersaing dengan manusia, oleh karena itu, dibutuhkan pakan alternatif. Adapun syaratsyarat pakan ternak yaitu, komposisi nutrisi terpenuhi, harga bersaing, tidak bersaing dengan manusia dan ketersediaan banyak serta berkesinambungan.

Kelima syarat tersebut dapat dipenuhi oleh maggot lalat tentara hitam (BSF) (Hermetia illucens) yaitu produksinyasangat cepat, mampu tumbuh dan berkembang biak dengan mudah pada media limbah (Wardhana 2016). Kadar protein kasar yang dikembangkan pada media bungkil kelapa sawit yaitu 44,01\% (Rachmawati et al. 2015), sedangkan yang dipelihara dengan media bungkil kelapa mengandung protein kasar 39,95\% (Diener, dkk., 2009)).Tinggi rendahnya nutrisi maggot BSF dipengaruhi oleh media tumbuh

Berdasarkan hal tersebut menjadi dasar dilakukan penelitian ini, terkait media tumbuh maggot yang berbeda. Penelitian ini menggunakan media dari limbah yaitu feses ayam dengan ampas tahu.Harapan dilakukan penelitian ini yaitu mengoptimalikan kandungan nutrisi maggot BSF dengan menggunakan media dari limbah.

\section{Metode Penelitian}

Penelitian ini dilaksanakan di Mini Rancs petrenakan, Universitas AL-Asyariah Mandar dan akan dilanjutkan dengan analisis laboratorium di Laboratorium Kimia Pakan Fakultas Peternakan Universitas Hasanuddin Makassar yang berlangsung selama 1 (Satu) bulan yaitu mulai bulan Mei Juli 2019

Alat yang digunakan yaitu baskom, tali rapiah, kain kasah, timbangan dan alat untuk analisis proksimat. Sedangkan bahan yang digunakan yaitu feses ayam,ampas tahu, magot dan bahan analisis proksimat.

Prosedur penelitian yaitu semua bahan untuk media tumbuh ditimbang dan di campur sesuai dengan perlakuan masing-masing. Setiap ember (unit percobaan) diisi $2 \mathrm{~kg}$ sesuai dengan perlakuannya.Selanjutnya setiap unit percobaan (ember) ditambahkan 5g maggot BSF dan dipelihara selama 25 hari.

Penelitian ini dirancang dengan menggunakan metode RAL dengan 4 perlakuan 3 ulangan, sehingga jumlah unit percobaan yaitu 12 .

$$
\begin{aligned}
& \mathrm{P} 1=\text { ampas tahu } 100 \% \\
& \mathrm{P} 2=\operatorname{ampas} \text { tahu } 50 \%+\text { feses ayam } 50 \% \\
& \mathrm{P} 3=\text { ampas tahu } 75 \%+\text { feses ayam } 25 \% \\
& \mathrm{P} 4=\text { ampas tahu } 25 \%+\text { feses ayam } 75 \%
\end{aligned}
$$

Data yang diperoleh dianalisis sidik ragam, selanjutnya apabilah perlakuan menunjukkan pengaruh yang nyata, maka dilanjutkan dengan Uji Duncan dengan menggunakan SPSS 22. 
Adapun model sebagai berikut:

Di mana :

$$
\mathbf{Y i j}=\boldsymbol{\mu}+\boldsymbol{\tau} \mathbf{i}+\varepsilon \mathbf{i j}
$$

Yij =Nilai pengamatan dari beberapa media tehadap pertumbuhan maggot ke-i dalam ulangan ke-j

$\mathrm{i}=$ Perlakuan P1, P2, P3, P4,P5

$\mathrm{j}=$ Ulangan $1,2,3$

$\mu \quad=$ Nilai tengah umum

$\tau \mathrm{i}=$ Pengaruh nilai nutrisi maggot dengan berbagai media yang berbedake-i

$\varepsilon_{i j}=$ Pengaruh Maggot dengan berbagai media ke-i terhadap Nilai nutrisimaggot ke-j.

\section{Hasil dan Pembahasan}

\subsection{Bahan Kering}

Kadar bahan kering bahan kering maggot BSF (Hermetia illucens) dipengaruhi oleh media tumbuh.Hasil analisis proksimat yang diperoleh menunjukkan kadarbahan kering maggot lalat tentara hitam (Hermetia illucens)denganmedia yang berbeda dapat dilihat pada Tabel 1

Tabel 1. Kadar Bahan Kering Magot Lalat Tentara Hitam (Hermetia illucens) dengan Media yang Berbeda.

\begin{tabular}{ccccc}
\hline \multirow{2}{*}{ Ulangan } & \multicolumn{4}{c}{ Perlakuan (\%) } \\
\cline { 2 - 5 } & $\mathrm{P} 1$ & $\mathrm{P} 2$ & $\mathrm{P} 3$ & $\mathrm{P} 4$ \\
\hline 1 & 30,40 & 29,09 & 28,75 & 13,21 \\
2 & 28,31 & 27,95 & 29,99 & 14,35 \\
3 & 28,48 & 28,51 & 32,68 & 15,59 \\
Rata-rata & $29,06^{\mathrm{b}} \pm 1.16$ & $28,52^{\mathrm{b}} \pm 0.57$ & $30,47^{\mathrm{b}} \pm 2.01$ & $14,38^{\mathrm{a}} \pm 1.18$
\end{tabular}

Keterangan: Huruf yang Berbeda pada Superscript Angka RataRata, Berbeda Nyata $(\mathrm{P}<0.05)$

Beradasarkan sidik ragam lama pemeliharaan yang berbeda pada maggot lalat tentara hitam (Hermetia illucens) berpengaruh sangat nyata $(\mathrm{P}<0.05)$ terhadap kadar bahan kering. Pada Tabel 1 menunjukkan mengalami peningkatan pada media P3 dan paling rendah pada P4.

Hasil uji Duncan menunjukkan bahwa perlakauan $\mathrm{P}_{1}$ tidak berbeda nyata $(\mathrm{P}>0.05)$ dengan $\mathrm{P}_{2}, \mathrm{P}_{3}$, tetapi berbeda nyata pada $\quad \mathrm{P}_{4}(\mathrm{P}<0.05) . \quad \mathrm{P}_{2}$ tidak berbeda nyata dengan $\mathrm{P}_{3}(\mathrm{P}>0.05) \quad$ tetapi berbeda dengan $\mathrm{P}_{4}(\mathrm{P}<0.05)$. Perlakuan $\mathrm{P}_{3}$, berbeda nyata $\mathrm{P}_{4}(\mathrm{P}>0.05)$.

Peningkatan bahan kering setiap perlakuan disebabkan maggot memakan nutrisi media dan dikonversi dalam tubuhnya.Semakin tinggi penggunaan feses ayam maka semakin tinggi bahan kering semakin banyak media dimakan dan mengkonversi nutrisi media dalam tubuh.Produksi bahan kering perlakuan P3 tinggi disebabkan kandungan bahan kering media dan mudah dicerna oleh maggot Hermetia illucens.

Bahan kering yang tinggi pada media perlakuan P3 yaitu dari bahan organic hasil fermentasi mikroorganisme.Bahan organik hasil fermentasi berupa asam lemak terbang dan protein kasar dari media maupun dari enzim mikroorganisme. (Li et al., 2011) Maggot Hermetia illucensmengubah nutrient dari media feses ternak menjadi protein dan lemak 10 jenisasam lemak telah terdeteksi, termasukasam palmitat, asam oleat dan asam linolenat dan sebagainya.(Tomberlin et al., 2009)Individu yang diberi pakan kadar nutrisi rendah memiliki cadangan lipid yang lebih sedikit dibandingkan maggot dengan pakan nutrisi tinggi.

\subsection{Protein Kasar}

Protein kasar maggot lalat tentara hitam Hermetia illucens dengan dengan penggunaan media yang berbeda disajikan pada Tabel 2.

Tabel 2. Kadar Protein Kasar Magot Lalat Tentara Hitam (Hermetia Illucens) dengan Media yang Berbeda.

\begin{tabular}{ccccc}
\hline \multirow{2}{*}{ Ulangan } & \multicolumn{4}{c}{ Perlakuan (\%) } \\
\cline { 2 - 5 } & $\mathrm{P} 1$ & $\mathrm{P} 2$ & $\mathrm{P} 3$ & $\mathrm{P} 4$ \\
\hline 1 & 33.00 & 49,88 & 43,82 & 25,30 \\
2 & 38,53 & 39,49 & 40,77 & 26,11 \\
3 & 44,24 & 35,71 & 44,36 & 27,61 \\
Rata-rata & $38,5^{\mathrm{b}} \pm 5.62$ & $41,69^{\mathrm{b}} \pm 7.33$ & $42,98^{\mathrm{b}} \pm 1.93$ & $26,34^{\mathrm{a}} \pm 1.17$ \\
\hline
\end{tabular}

Keterangan: Huruf yang Berbeda pada Superscript Angka RataRata, Berbeda Nyata $(\mathrm{P}<0.05)$

Berdasarkan analisis sidik ragam menunjukkan media yang berbeda pada maggot lalat tentara hitam(Hermetia illucens) berpengaruh nyata $(\mathrm{P}<0.05)$ terhadap kadar protein kasar maggot. Berdasarkan Tabel 2 menunjukkan kadar protein tertinggi pada perlakuan $\mathrm{P} 3$ dan terndah pada perlauan P4.

Hasil uji Duncan menunjukkan bahwa perlakauan P1 tidak berbeda nyata $(\mathrm{P}>0.05)$ dengan $\mathrm{P} 2, \mathrm{P}$, tetapi berbeda nyata pada $\mathrm{P} 4(\mathrm{P}<0.05)$. $\mathrm{P} 2$ tidak berbeda nyata dengan $\mathrm{P} 3$ $(\mathrm{P}>0.05)$ tetapi berbeda denganP4 $(\mathrm{P}<0.05)$. Perlakuan $\mathrm{P} 3$, berbeda nyataP4 $(\mathrm{P}<0.05)$.

Kadar protein kasar berbanding lurus dengan kadar bahan kering maggot. Kadar protein kasar yang paling tinggi pada P3 $(42.98 \%)$ dan paling rendah pada P4 (26.34\%). Kadar protein yang tinggi pada P3 disebabkan karena kadar protein media dengan menggunaan media ampas tahu $75 \%$ dan feses ayam $25 \%$. Rendahnya kadar protein pada perlakuan $\mathrm{P} 4$ karena penggunaan media ampas tahu $25 \%$ dan feses ayam $75 \%$. Hal ini sesuai dengan hasil penelitian (Cicilia and Susila 2012) bahwa jenis asam amino pada maggot Hermetia illucens yaitu asam glutamat, asam aspartat, alanin, tirosin, valin, lisin dan leusin. (Suciati and Faruq, 2017) Komposisi media mempunyai pengaruh yang cukup signifikan terhadap kadar maggot yang dihasilkan, kandungan protein maggot BSF sangat ditentukan oleh kandungan protein media tumbuhnya.

Larva Hermetia illucens memilki enzim protease dalam system pencernaannya, sehingga mampu mencerna berbagai jenis bahan organik kemudian merombaknya menjadi protein (Kim et al. 2011). Kandung nutrisi pakan yang diberikan pada mggot, kurang lebih biomassa larva perpupa. Penyimpanan protein dan karbohidrat terdapat pada proporsi massa pada eklosi dewasa ditandai dengan pertumbuhan somatik. Proporsi protein dan karbohidrat yang disimpan dalam tubuh tidak berbeda dengan pakan perlakuan yang diberikan (Hahn 2005)

\subsection{Serat Kasar}

Serat kasar maggot lalat tentara hitam Hermatia illucens dengan media yang berbeda disajikan pada Tabel 3 . 
Tabel 3. Kadar Serat Kasar Magot Lalat Tentara Hitam (Hermetia Illucens) dengan Media yang Berbeda

\begin{tabular}{ccccc}
\hline Ulanga & \multicolumn{4}{c}{ Perlakuan (\%) } \\
\cline { 2 - 5 } $\mathrm{n}$ & $\mathrm{P} 1$ & $\mathrm{P} 2$ & $\mathrm{P} 3$ & $\mathrm{P} 4$ \\
\hline 1 & 7,99 & 10,55 & 7,04 & 13,71 \\
2 & 8,93 & 14,33 & 12,96 & 12,15 \\
3 & 9,24 & 20,33 & 11,21 & 12,32 \\
Rata-rata & $8,72 \pm 0.65$ & $15,07 \pm 4.93$ & $10,40 \pm 3.04$ & $12,73 \pm 0.85$ \\
\hline
\end{tabular}

Beradasarkan sidik ragam menunjukkan lama pemeliharaan yang berbeda pada maggot lalat tentara hitam (Hermetia illucens) tidak berpengaruh sangat nyata $(\mathrm{P}>0.05)$ terhadap serat kasar. Tabel 3 menunjukkankadar serat kasar paling tinggi pada media $\mathrm{P} 2$ dan paling rendah pada $\mathrm{P} 1$.

Kadar serat kasar yang tinggi pada P2 disebabkan kadar serat pada media. Salah satu jenis serat kasar yang susah dirombak menjadi karbohidrat sederhana yaitu lignin. Lignin yang terdapat di dalamnya merupakan jenis serat yang susah diubah menjadi asam lemak. (Kim et al. 2011)larva lalat tentara hitam (Hermetia illucens) di saluran pencernaannya terdapat mekroorganisme pencerna lignin diubah menjadi selulosa sumebr energy untuk maggot. (Li et al. 2015; Yu et al. 2011) lignicellulose mengubah lignin menjadi gula sederhana yang merupakan enzim yang dihasilkan oleh larva lalat tentara hitam (Hermetia illucens).

\subsection{Lemak Kasar}

Lemak kasar maggot lalat tentara hitam Hermetia illucens dengan media yang berbeda dapat dilihat pada Tabel 4. Bedasarkan hasil analisis sidik ragam menunjukkan penggunaan media dengan penambahan feses ayam signifikan mempengaruhi turunnya lemak kasar pada maggot lalat tentara hitam (Hermetia illucens) $(\mathrm{P}<0.05)$.

Tabel 4. Kadar Lemak Kasar Magot Lalat Tentara Hitam (Hermetia Illucens) dengan Media yang Berbeda

\begin{tabular}{ccccc}
\hline Ulang & \multicolumn{4}{c}{ Perlakuan $(\%)$} \\
\cline { 2 - 5 } an & $\mathrm{P} 1$ & $\mathrm{P} 2$ & $\mathrm{P} 3$ & $\mathrm{P} 4$ \\
\hline 1 & 40,45 & 8,46 & 28,42 & 16,71 \\
2 & 38,53 & 31,03 & 38,77 & 14,18 \\
3 & 39,24 & 20,33 & 35,07 & 15,23 \\
Rata-rata & $39,41^{\mathrm{b}} \pm 0.97$ & $19,94^{\mathrm{a}}+11.29$ & $34,09^{\mathrm{b}}+5,24$ & $15,37^{\mathrm{a}}+1.27$
\end{tabular}

$\frac{\text { Rata-rata } 39,41^{\mathrm{b}} \pm 0.97 \quad 19,94^{\mathrm{a}} \pm 11.29 \quad 34,09^{\mathrm{b}} \pm 5.24 \quad 15,37^{\mathrm{a}} \pm 1.27}{\text { Keterangan: Huruf yang Berbeda pada Superscript Angka Rata- }}$ Rata, Berbeda Nyata $(\mathrm{P}<0.05)$.

Hasil analisis sidik ragammenunjukkan penggunaan media dengan penambahan feses ayam signifikan mempengaruhi turunnya lemak kasar pada maggot lalat tentara hitam (Hermetia illucens) $(\mathrm{P}<0.05)$.

Hasil uji Duncan menunjukkan bahwa perlakauan $\mathrm{P}_{1}$ tidak berbeda nyata $(\mathrm{P}>0.05)$ dengan $\mathrm{P}_{3}$ dan berbeda nyata $(\mathrm{P}<0.05)$ dengan $\mathrm{P} 2$ dan $\mathrm{P} 4 . \mathrm{P}_{2}$ berbeda nyata dengan $\mathrm{P}_{3}(\mathrm{P}<0.05)$ tetapi tidak berbeda nyata $(\mathrm{P}>0.05)$ dengan $\mathrm{P}_{4}$. Perlakuan $\mathrm{P}_{3}$, berbeda nyataP $\mathrm{P}_{4}(\mathrm{P}<0.05)$.
Penelitian ini menunjukkan bahwa semakin tingginya penggunaan media ampas tahu maka kadar lemak kasar maggot semakin tinggi. Lemak yang terdapat pada maggot berupa asam lemak dari media yang dikonsumsi dengan bantuan enzim lipase yang terdapat pada maggot Hermetia illucens.(Fahmi et al., 2009)Agen perombak limbah hewani yang sering ditemukan adalh larva serangga Dieptra dari famili Challifora, larva serangga dari Limbah-limbah hewani agen perombak yang sering ditemukan adalah larva serangga Diptera dari famili Challifora. Larva serangga dari famili: Stratiomydae, Genus: Hermetia, spesies: Hermetia illucens.

\section{Kesimpulan}

Berdasarkan analisa data dapat disimpulkan kualitas produksi nutrisi paling tinggi pada perlakuan P3 dengan kadar bahan kering 30,47\%, protein kasar 42,98\%, lemak kasar 34,09\%, dan serat kasar 10,40\%.

\section{Daftar Pustaka}

Cicilia, Asi Pebrina, and Nyata Susila. 2012. "Potential of Tofu Dregs on The Production of Maggot ( Hermetia Illucens ) as a Source of Protein of Fish Feed." Jurnal anterior 18(1): 40-48.

Diener, Stefan, Christian Zurbrügg, and Klement Tockner. 2009. "Conversion of Organic Material by Black Soldier Fly Larvae: Establishing Optimal Feeding Rates." Waste Management and Research 27(6): 603-10.

Fahmi, R., S. Melta, W Hem, and I W.Subamia. 2009. "Maggot Potential to Increase Growth and Improve Health Status of Fish." J. Ris. Akuakultur 4(2): 221-32.

Hahn, Daniel A. 2005. "Larval Nutrition Affects Lipid Storage and Growth , but Not Protein or Carbohydrate Storage in Newly Eclosed Adults of the Grasshopper Schistocerca Americana." journal Insect Physiology 51: 1210-19.

Kim, W et al. 2011. "Biochemical Characterization of Digestive Enzymes in the Black Soldier Fly, Hermetia Illucens (Diptera: Stratiomyidae)." J. of Asia-Pasific Entomology 14: 11-14.

Li, Qing et al. 2011. "Bioconversion of Dairy Manure by Black Soldier Fly ( Diptera: Stratiomyidae ) for Biodiesel and Sugar Production Bioconversion of Dairy Manure by Black Soldier Fly ( Diptera : Stratiomyidae ) for Biodiesel and Sugar Production." WASTE MANAGEMENT http://dx.doi.org/10.1016/j.wasman.2011.01.005.

Li, W et al. 2015. "Simultaneous Utilization of Glucose and Xylose for Lipid Accumulation in Black Soldier Fly." Biotechnology for Biofuels 8(117).

Rachmawati et al. 2015. "Development and Nutrional Content of Hermetia Illucens (Linnaeus) (Diptera: Stratiomyidae) Larvae on Oilpalm Kernel." J. Entomol. Indon. 7(1): 28-41.

Tomberlin, Jeffery K et al. 2009. "Development of the Black Soldier Fly ( Diptera : Stratiomyidae ) in Relation to Temperature Development of the Black Soldier Fly ( Diptera: Stratiomyidae ) in Relation to Temperature." 38(3): 930-34.

Wardhana, April Hari. 2016. "Black Soldier Fly ( Hermetia Illucens ) as an Alternative Protein Source for Animal Feed." Wartazoa 26(2): 6978.

$\mathrm{Yu}, \mathrm{G}$ et al. 2011. "Inoculating Poultry Manure with Companion Bacteria Influences Growth and Development of Black Soldier Fly (Diptera: Stratiomyidae) Larvae.” Environmental Entomology 40(1): 30-35. 